\title{
PRODUCTION AND CHARACTERISATION OF ANTI-CARDIAC TROPONIN-I MONOCLONAL ANTIBODIES
}

\author{
KH.H. HAIDER* AND W.H. STIMSON ${ }^{*}$ \\ * Faculty of Pharmacy, University of the Punjab, Lahore, Pakistan \\ 'Department of Immunology, University of Strathclyde, The Todd Centre, Glasgow, U.K.
}

\begin{abstract}
SUMMARY
Cardiac troponin-I (cTn-I) was isolated from bovine left ventricular tissue and used as immunogen. Sixteen murine hybridoma lines were produced with two of them, 1D12 and 5F4, showing a high specificity for $\mathrm{CTn}-\mathrm{I}$; both of these monoclonal antibodies (McAbs) were isotyped as $\operatorname{IgG}_{1}$ with kappa - light chains. The specificity of the McAbs for cTn-I was confirmed by ELISA, western blotting and by the ability of the antibodies to block actomyosin ATPase inhibition by cTn-I. The McAbs may be useful for human in vivo imaging of myocardial infarcts and other pathological conditions related to cardiac myocyte damage.
\end{abstract}

KEY WORDS Cardiac troponin-I Monoclonal antibodies Myocardial infarcts Myocardial damage

\section{INTRODUCTION}

The advent and advancement of thrombolytic therapy has significantly affected the management of patients with acute myocardial infarction (AMI) (Verstraete, 1992). The familiar triad of clinical history, ECG and serum enzyme analysis, is still of some significance in the diagnosis of MI (Willerson, 1989). However, none of these criteria reveal quantitative and precise information regarding the extent and location of the infarct. Also, although studies have been made to correlate infarct size with changes in the blood concentrations of the marker molecules released from necrosing myocytes they have met with little success (Serrano et al., 1990; Vaananen et al., 1990; Doran and Fleck, 1990; Prager et al., 1992).

The physical destruction of the dying cardiac cells is an irreversible phenomenon which causes a loss in the ability of the cells to maintain the ionic balance with the surrounding tissue. The leakage of macromolecular contents from cells, which have lost membrane integrity, has become an area of interest in the identification of cardiac specific markers. Amongst these macromolecules, the contractile and regulatory proteins of the myocardium are considered to be of particular significance (Cummins et al., 1987). This is due to the expression of the cardiac-specific isoforms of these proteins, their higher intracellular concentration (Swynghedauw, 1986) and continuous release from the infarcting myocardium (Leger et al., 1985, Katus et al., 1992). In the past, polyclonal antibodies (Khaw et al., 1976; Cummins et al., 1987)

Correspondence to: Department of Immunology, University of Strathclyde, The Todd Centre, 31 Taylor Street, Glasgow. G4 0NR, U.K. 
and affinity purified antibodies (Cummins et al., 1990), raised against cardiac proteins, have been examined in vitro as well as in experimentally-induced myocardial infarctions.

Since the advent of monoclonal antibody technology (Kohler \& Milstein, 1975), this type of antibody has been produced against a number of contractile and regulatory proteins of heart muscle (Khaw et al., 1984; Katus et al., 1989; Jin et al., 1990; Ladenson et al., 1990; Larue et al., 1992, 1993). Following these results, we report the development of unique McAbs against Tn-I that are highly specific for its cardiac isoform.

Troponin-I is the inhibitory component of the troponin complex (Tsukui and Ebashi, 1973). It has been reported to exist in three isoforms, encoded by three different genes (Hunkler et al., 1991) with distribution of the cardiac specific form, mol wt $24 \mathrm{Kd}$, only in the cardiac muscle. cTn-I is considered to be of significance for both the in vitro as well as in vivo diagnosis of MI due to its cardiac specificity, uniform distribution in the cardiac muscle, unique location in myofibrillar structure and release characteristics from the necrotising cardiac tissue in the event of MI (Cummins et al., 1987, 1990; Haider and Stimson, 1993).

\section{MATERIALS AND METHODS}

\section{Purification of cardiac proteins}

The extraction method described by Syska et al. (1974) was modified for the purification of cardiac proteins from bovine heart. Cardiac tissue was obtained 1-10 h after death and stored at $-70^{\circ} \mathrm{C}$ until required. Bovine, ovine, human and rabbit cardiac tissue, $5-50 \mathrm{~g}$ was homogenised in 10 volumes of buffer containing $9 \mathrm{M}$ urea, $1 \mathrm{mM} \mathrm{CaCl}_{2}$, $60 \mathrm{mM} 2$-mercaptoethanol and $5 \mathrm{mM}$ Tris $/ \mathrm{HCl}, \mathrm{pH} 8.0$ at $4^{\circ} \mathrm{C}$ in a Warring blender and centrifuged at $10,000 \mathrm{rpm}$ for $20 \mathrm{~min}$. The supernatant was passed through glass wool and adjusted to $35 \%\left(\mathrm{NH}_{4}\right)_{2} \mathrm{SO}_{4}$ saturation by the slow addition of saturated ammonium sulphate solution with constant stirring at $4^{\circ} \mathrm{C}$ for $1 \mathrm{~h}$. The precipitate was then removed by centrifugation at $10,000 \mathrm{rpm}$ for $20 \mathrm{~min}$ and the supernatant adjusted to $50 \%$ $\left(\mathrm{NH}_{4}\right)_{2} \mathrm{SO}_{4}$ saturation. After stirring for $1 \mathrm{~h}$, it was centrifuged at $10,000 \mathrm{rpm}$ for $20 \mathrm{~min}$ and the precipitate redissolved in $0.1 \mathrm{M}$ citrate buffer, $\mathrm{pH}$ 6.0. This crude cardiac extract was dialysed overnight against the same buffer, centrifuged at 20,000 rpm and concentrated by ultrafiltration (PM10 membrane, Amicon). Finally, the was purified on a Sephadex G75-SF column $(1.6 \times 95 \mathrm{~cm})$ with $0.1 \mathrm{M}$ sodium citrate buffer, $\mathrm{pH} 6.0$, as eluent. One millilitre fractions were pooled separately for cTn-I and used for further experimentation.

\section{Actomyosin ATPase inhibition assay}

The inhibitory activity of purified cTn-I on skeletal actomyosin ATPase (Sigma) activity, in the presence of an equal concentration of cardiac tropomyosin (cTm), was determined as described by Brekke and Greaser (1976). The assay was performed with skeletal actomyosin $(0.3 \mathrm{mg})$ in $1 \mathrm{ml} 25 \mathrm{mM}$ Tris/ $\mathrm{HCl}$ buffer, $\mathrm{pH} 7.4$, containing $25 \mathrm{mM}$ $\mathrm{KCl}, 5 \mathrm{mM} \mathrm{MgCl}_{2}$ and $10 \mathrm{mM} \mathrm{CaCl}_{2}$ at $25^{\circ} \mathrm{C}$. The reaction was initiated by the addition of $50 \mu \mathrm{l} 0.1 \mathrm{M}$ ATP solution and after $10 \mathrm{~min}$ it was stopped with $1 \mathrm{ml} 20 \%$ trichloroactic acid. The inorganic phosphate released during the reaction was determined by the Fiske Subarow method (Mark and Zimmer, 1967). 


\section{Monoclonal antibody production}

Immunisation of 6-8w, female BALB-c/NZB F1 hybrid mice was performed with pure

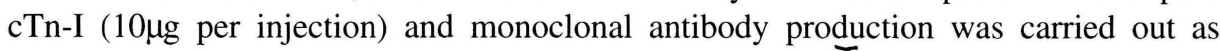
described previously (Islam and Stimson, 1987). Hybridoma cell lines were propagated in pristane-primed histocompatible mice at a cell density of $5 \times 10^{6} / 0.5 \mathrm{ml}$ RPMI 1640 culture medium, for ascites production. Antibodies were purified from ascites by $50 \%\left(\mathrm{NH}_{4}\right)_{2} \mathrm{SO}_{4}$ fractionation and then by affinity chromatography using Protein A. These were conjugated with horse radish peroxidase (HRP) as described by Nkane and Kawaoi (1974) for use in a direct ELISA for cTn-I. Isotype analysis of the antibodies was carried out by ELISA using isotype-specific HRP-conjugated goat anti-mouse antisera (BioRad).

\section{ELISA for screening hybridomas}

Plates were coated with crude bovine cTn-I $(5 \mu \mathrm{g} / \mathrm{ml}-100 \mu \mathrm{l} /$ well $)$ in $10 \mathrm{mM}$ Tris/HCl buffer, $\mathrm{pH}$ 9.0, and incubated overnight at room temperature (RT). Plates were washed $\mathrm{x} 4$ with $20 \mathrm{mM}$ Tris/ $\mathrm{HCl}$ wash buffer, $\mathrm{pH} 7.4$, containing $0.05 \%$ Tween 20 and incubated at $37^{\circ} \mathrm{C}$ for $1 \mathrm{~h}$ with $250 \mu \mathrm{l} /$ well blocking solution $(10 \%$ newborn calf serum in wash buffer); these were again washed $\mathrm{x} 4$ with the buffer and then incubated at $37^{\circ} \mathrm{C}$ for $1 \mathrm{~h}$ with $100 \mu$ hybridoma cell supernatant/well. Following treatment with wash buffer $(\mathrm{x} 4)$ $100 \mu \mathrm{l}$ anti-mouse IgG-HRP conjugated antibody was added to each well for $1 \mathrm{~h}$ at $37^{\circ} \mathrm{C}$. Finally, plates were washed $\mathrm{x} 4$ and enzyme activity assessed by incubation at RT with TMB substrate $(250 \mu \mathrm{l}$ stock TMB solution in $25 \mathrm{ml}$ sodium acetate buffer and $4 \mu \mathrm{l} 30 \%$ $\mathrm{H}_{2} \mathrm{O}_{2}$ solution) for $30 \mathrm{~min}$ in the dark. The reaction was stopped by the addition of $50 \mu \mathrm{l}$, $10 \%(\mathrm{v} / \mathrm{v}) \mathrm{H}_{2} \mathrm{SO}_{4} /$ well and the $\mathrm{A}_{450}$ measured.

\section{ELISA on the fractions eluted from the gel filtration column}

The eluted fractions from the Sephadex G75-SF column were adjusted to $\mathrm{pH} 9.0$ with $0.1 \mathrm{M} \mathrm{NaOH}$ solution. An ELISA plate was coated with $100 \mu \mathrm{l}$ of each fraction per well, in duplicate. The immunoassay was then carried out using the 1D12 or 5F4 anti-cTn-I specific McAbs as described above.

Inhibitory effect of the anti-cTn-I McAbs on cTn-I inhibition of actomyosin ATPase activity

cTn-I and cTm, in a 1:1 ratio were mixed with $30 \mu \mathrm{l}$ purified 5F4 or $1 \mathrm{D} 12 \mathrm{McAbs}$ and left for $1 \mathrm{~h}$ at RT. The actomyosin ATPase inhibition assay was then carried out as before. Increasing concentrations of cTn-I and cTm were used in the presence of the antibodies in volumes of 30,60, 120,180, 240 and $300 \mu l$.

\section{Electrophoresis and Western blotting:}

Crude cardiac proteins or pure cTn-I were resolved on one dimensional SDS-PAGE gels containing $10 \% \mathrm{~T}$ and $2.6 \% \mathrm{C}$ with a discontinuous buffer system (Lammeli, 1970).

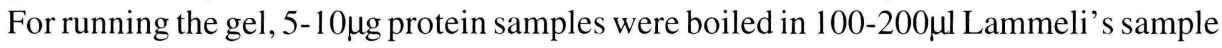
buffer for $5 \mathrm{~min}$. They were applied at a loading concentration of $2.5-5 \mu \mathrm{g}$ protein $/ 50 \mu \mathrm{l}$ sample buffer per well. Electrophoresis was carried out at $100 \mathrm{~V}$ for $8 \mathrm{~h}$ using $0.1 \mathrm{M}$ Tris/ glycine buffer, $\mathrm{pH} 8.3$.

For Phast Gel SDS-PAGE, a pre-cast homogeneous gel, $45 \mathrm{~mm}$ thick containing $12.5 \% \mathrm{~T}$ and $2 \% \mathrm{C}$ (Pharmacia) was used with SDS-buffer strips (Pharmacia). Proteins 
samples, $1 \mu \mathrm{l}$, were loaded using a sample applicator ( 8 slots with $1 \mu \mathrm{l}$ capacity per slot) at a loading concentration of $0.5-1 \mu \mathrm{g}$ protein/ $\mu \mathrm{l}$ of sample buffer for each track. For visualisation of proteins, the gels were stained either with Coomassie blue or silver , as described by Morrisey, 1981.

For immunoblot analysis, proteins from SDS-PAGE were transferred to a nitrocellulose membrane using $0.1 \mathrm{M}$ Tris/glycine buffer, $\mathrm{pH} 8.3$, at a constant current of $80 \mathrm{~V}$ for 16-18 $\mathrm{h}$ in a Transblot apparatus (BioRad), as described by Towbin et al., 1979. After transfer of proteins the membrane was incubated at RT for $1 \mathrm{~h}$ with $5 \%$ casein solution in $50 \mathrm{mM}$ Tris $/ \mathrm{HCl}, \mathrm{pH} 7.4$, (wash buffer). The blot was treated $\mathrm{x} 3$ with wash buffer and incubated with anti-cTn-I McAb in PBS containing 1\% BSA. After extensive washing, the blot was incubated for $1 \mathrm{~h}$ at RT with sheep anti-mouse IgG HRP-conjugated antibody $(1: 200)$ in PBS containing $25 \%(\mathrm{v} / \mathrm{v})$ sheep serum. Finally, the blot was washed $\mathrm{x} 3$ in wash buffer and soaked for $2 \mathrm{~min}$ in substrate solution $(6 \mathrm{mg}$ diaminobenzidine $/ 10 \mathrm{ml}$ $50 \mathrm{mM}$ Tris/ $\mathrm{HCl}$ buffer, $\mathrm{pH} 7.6,1 \mathrm{ml} 0.3 \% \mathrm{CoCl}_{2}$ solution in $\mathrm{H}_{2} \mathrm{O}$ and $10 \mu \mathrm{l} 30 \%(\mathrm{v} / \mathrm{v})$ $\mathrm{H}_{2} \mathrm{O}_{2}$.

\section{RESULTS}

\section{Purification of cTn-I}

Preparation of cTn-I and cTm was carried out by gel filtration following initial urea buffer extraction and partial purification by ammonium sulphate fractionation. Partial purification by salt fractionation (30-50\% saturation) resulted in a relatively pure cTnI preparation. This was further purified on a Sephadex G75-SF column and a plot of the elution profile of the cardiac proteins (Figure 1) shows that the elution volumes for cTnI and cTm were $106-110 \mathrm{ml}$ and $81-85 \mathrm{ml}$ respectively. These fractions were pooled, concentrated and used in later experimentation. The average yield of cTn-I and cTm obtained was $10-15 \mathrm{mg} / 50 \mathrm{~g}$ cardiac tissue. For determination of purity, the cTm and cTnI preparations were analysed by SDS-PAGE. The actomyosin ATPase inhibition assay showed that the cTn-I purified by this method retained its biological activity and caused $50-60 \%$ inhibition at $80 \mu \mathrm{g} / 0.3 \mu \mathrm{g}$ actomyosin concentration (Figure 2). Skeletal muscle troponin I (sTn-I), prepared by the same procedure, was employed as a positive control.

\section{Antibody production}

Six separate cell fusions were performed before stable, anti-cTn-I secreting hybridoma cell lines were obtained; these resulted in $70-80 \%$ of the wells seeded showing positive hybrid cell growth. However, sixteen cell lines were finally chosen and cloned by limiting dilution with two lines showing a particularly high specificity for cTn-I. These cell lines, 1D12 and 5F4, were selected for further characterisation and isotype analysis revealed that both were $\mathrm{IgG}_{1}$ kappa. The $1 \mathrm{D} 12$ and $5 \mathrm{~F} 4$ cell lines were grown successfully as ascites in pristane-primed mice and the McAbs purified by $50 \%$ $\left(\mathrm{NH}_{4}\right)_{2} \mathrm{SO}_{4}$ fractionation before conjugation to HRP for the direct ELISA (Islam and Stimson, 1987). A higher purification level of the 1D12 and 5F4 McAbs was achieved by Protein A affinity chromatography.

\section{ELISA on gel filtration fractions}

The results of the indirect ELISA carried out on the fractions obtained by gel filtration showed that the $1 \mathrm{D} 12$ and 5F4 McAbs reacted only with fractions containing cTn-I 


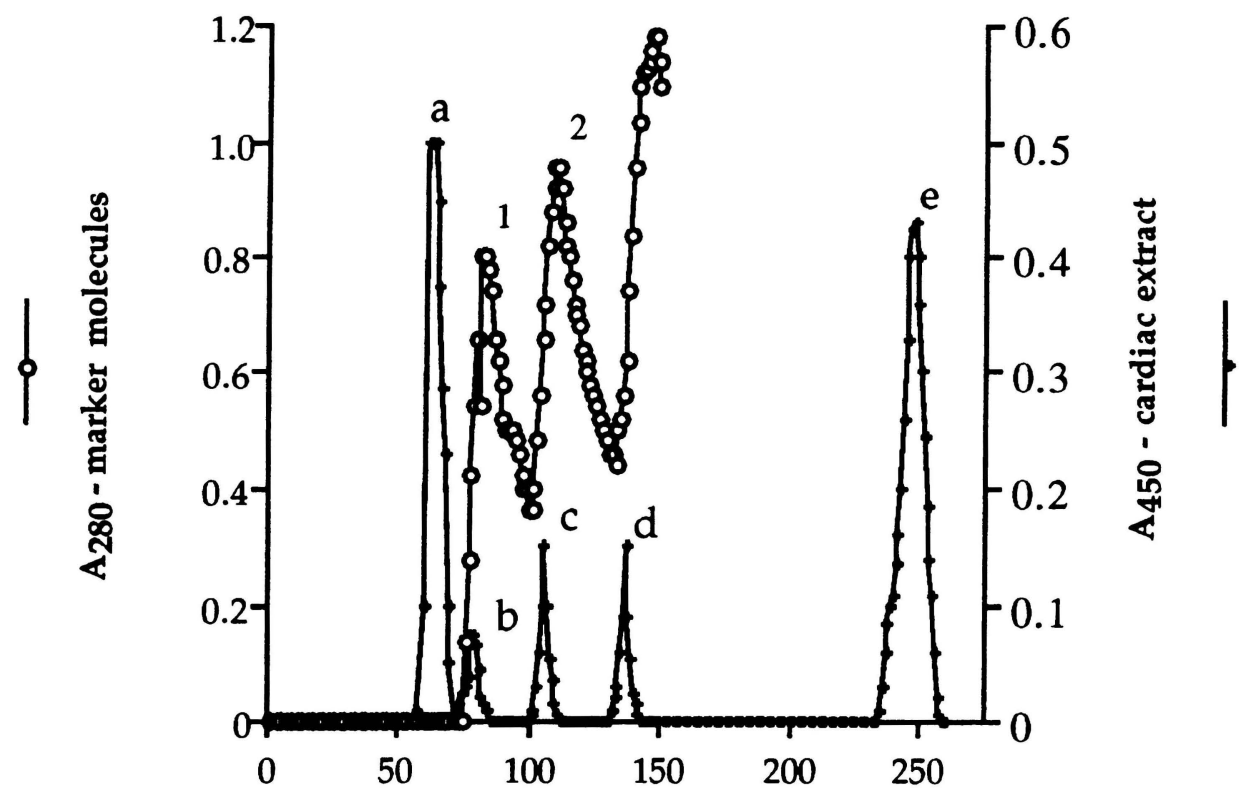

Fraction number

Figure 1. Elution profiles of the bovine cardiac protein extract and marker proteins on Sephadex G75-SF; (1) - cTm, (2)-cTn-I. Molecular weight markers: a - dextran blue, b- bovine serum albumin (66kd), c - carbonic anhydrase (29kd), d - cytochrome C (12.5kd), e - fluorescein.

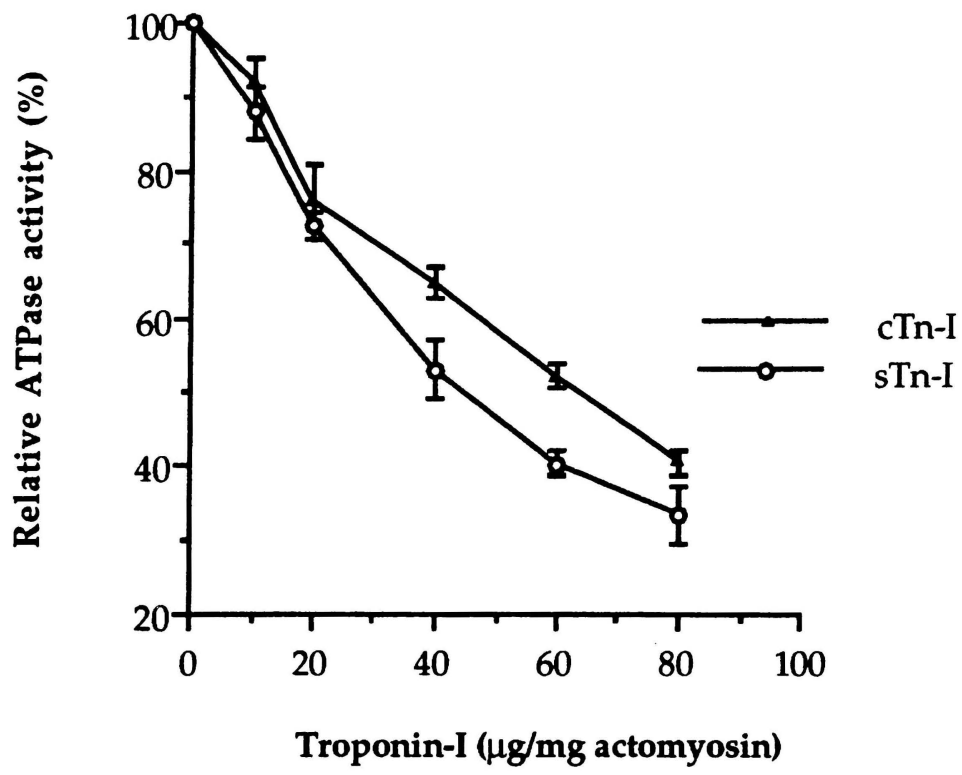

Figure 2. Inhibitory activity of cTn-I and sT-I on skeletal muscle actomyosin ATPase. Results are shown as the mean $\pm \mathrm{SD}$ of 3 separatedeterminations. 
(fractions 106-110) (Figure 3a,b). The reactivity of the antibodies for the other column fractions was found to be negligible (background levels). For confirmation of the validity of these results, the indirect 'Fraction ELISA' was carried out under the same conditions but using an unrelated antibody, 1D11 (Figure 3c).

\section{Inhibitory effect of $5 F 4$ and $1 D 12$ McAbs on ATPase inhibitory activity of cTn-I}

The inclusion of the 1D12 or 5F4 McAbs in the actomyosin ATPase inhibition assay by cTn-I completely blocked the inhibitory effect of cTn-I on actomyosin ATPase, thus confirming their specificity of the antibodies for cTn-I (Figure 4).

\section{SDS-PAGE and Western blotting}

ELISA showed that both the 1D12 and 5F4 McAbs recognised cTn-I. To confirm that these McAbs were specific for cTn-I, the binding of McAbs was analysed by SDS-PAGE of crude as well as pure cTn-I followed by immunoblot analysis; all the major cardiac protein components of the myocardium were resolved under these conditions. When the blots were probed with the $2 \mathrm{McAbs}$, reaction with a single protein band of $24 \mathrm{KD}$ was observed. This protein had previously been identified as cTn-I on the basis of its characteristics, viz. elution profile from the gel filtration column, mol.wt analysis on SDS-PAGE and the actomyosin ATPase inhibition assay. No reactivity of these McAbs was observed with any other cardiac protein. Figure 5 shows that McAb 5F4 identified only one component in crude cardiac extracts from human, bovine, ovine and rabbit tissues; identical results were obtained with ID12, using SDS-PAGE followed by Western blotting.

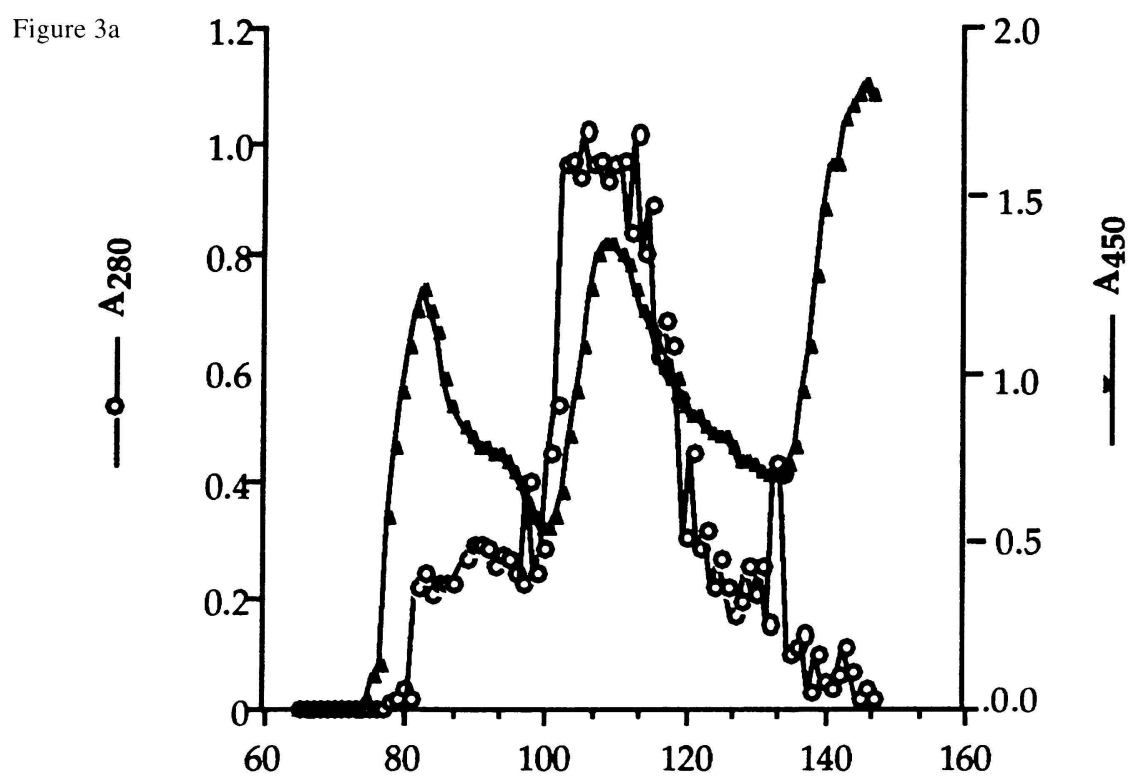

Fraction number 


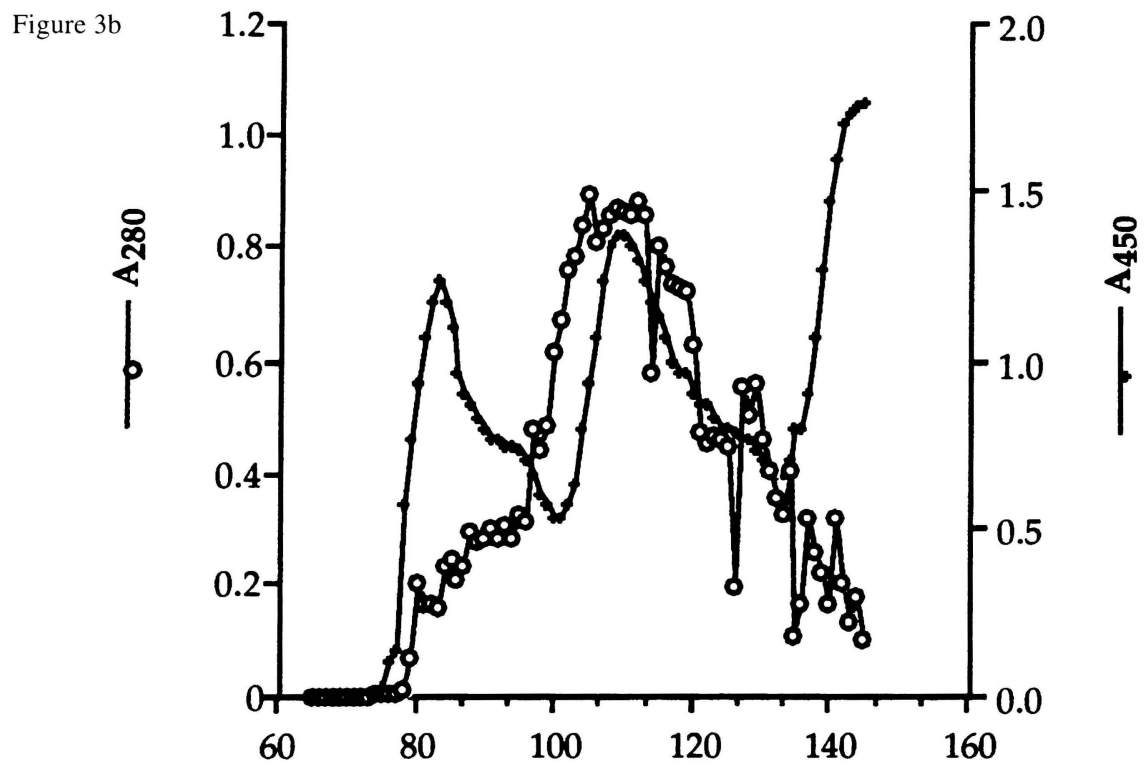

\section{Fraction number}

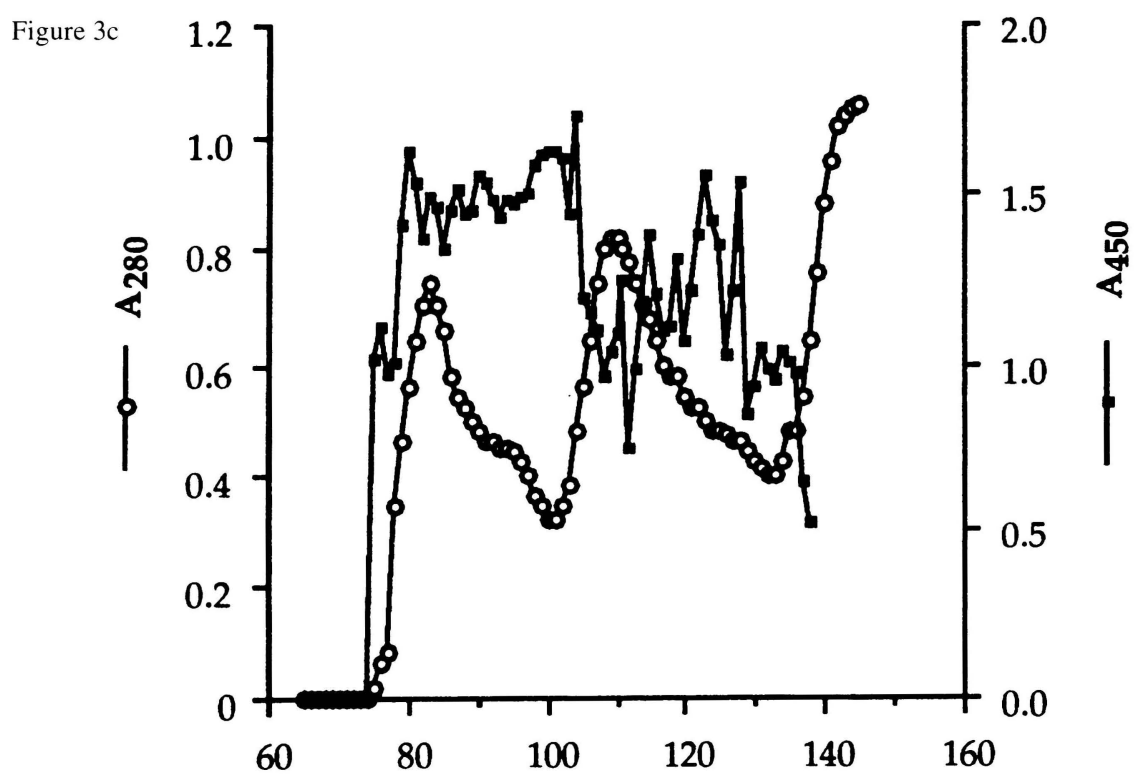

Fraction number

Figure 3. Indirect ELISA of fractions obtained from gel filtration of the crude bovine cardiac protein extract.

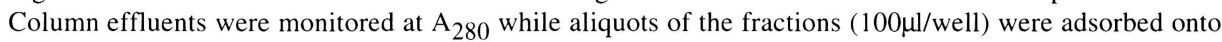
microtitre plates and detected by ELISA at $\mathrm{A}_{450}$ using (a) $1 \mathrm{D} 12$ (b) 5F4 (c) an unrelated McAb (1D11). 


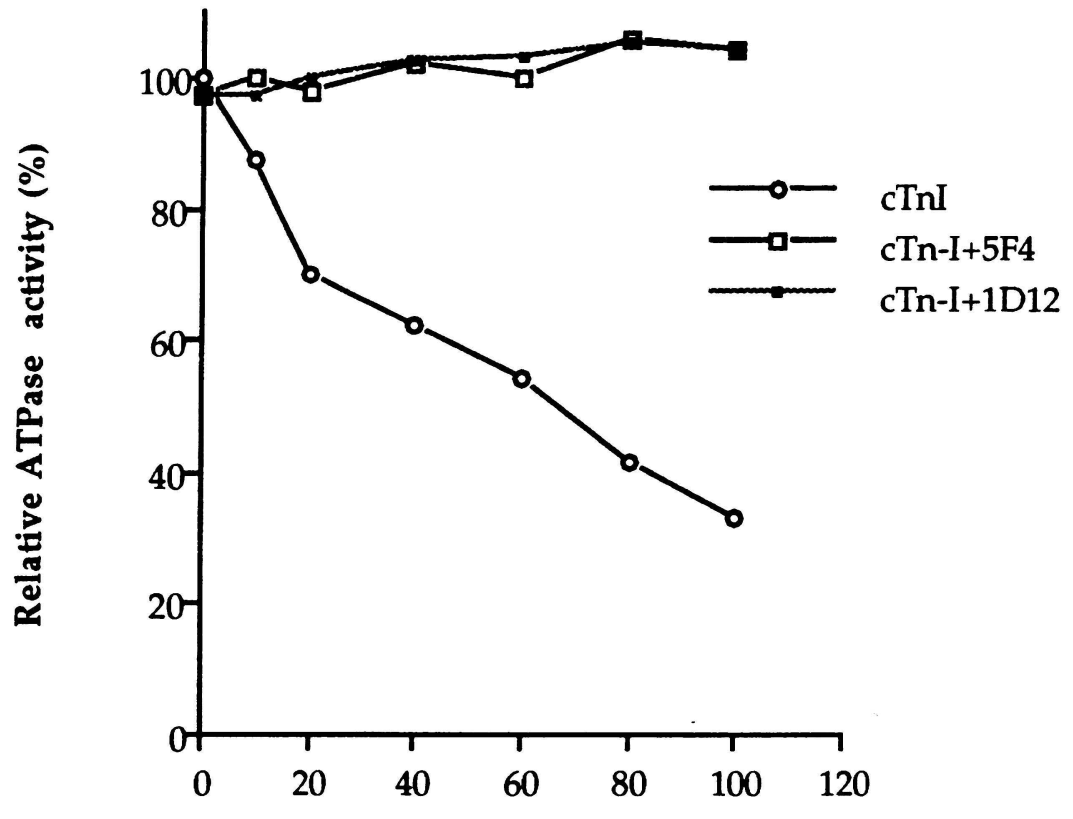

\section{Troponin-I ( $\mu \mathrm{g} / \mathrm{mg}$ actomyosin)}

Figure 4. Blocking of the inhibitory activity of $\mathrm{cTn}$-I on the ATPase activity of skeletal actomyosin by the anticTn-I McAbs, ID12 and 5F4.

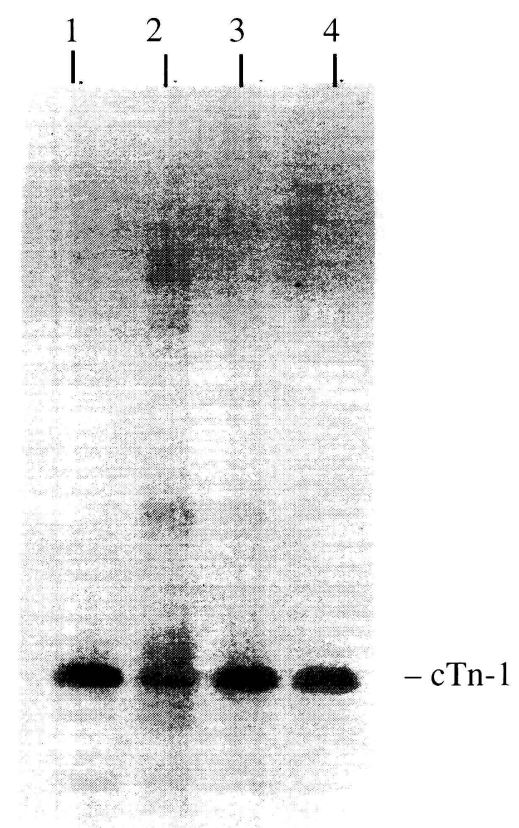

Figure 5. Western blotting of crude cardiac protein extracts using the 5F4 anti-cTn-I McAb. Lane 1 - human, Lane 2 - bovine, Lane 3 - ovine, Lane 4 - rabbit. 


\section{DISCUSSION}

Recently, various groups of research workers have reported McAbs with specificity for cTn-I (Bodor et al., 1990; Larue et al., 1992; Landenson et al., 1992; ). Most of these McAbs have been used for development of cTn-I specific immunoassays for the in vitro diagnosis of MI by estimation of serum cTn-I in patient blood samples. We are reporting here the development of cTn-I specific McAbs which have been successfully used in a brain death model in Landrace pigs (unpublished).

Considering the fact that cTn-I in mammalian cardiac tissue shows definite interspecies relationship (Cummins and Cummins, 1987), bovine cardiac tissue was used for extraction of cTn-I for use as immunogen because of its easy availability compared to human myocardium. Most of the procedures described in the literature for the purification of cTn-I involve the initial purification of the Tn-complex, with subsequent fractionation into individual components (Tsukui and Ebashi, 1973; Brekke and Greaser, 1976; Potter and Johnson, 1982). The relatively long isolation times used with multiple steps often lead to degradation of the component proteins, especially cTn-I, which is particularly susceptible to endogenous cathepsins (Katagiri, 1981). The method used in this study for purification of cTn-I was short, simple and less labour-intensive and it gave a high level of purity. In addition the cTn-I prepared by this method retained full biological activity.

The initial selection of the hybridoma cell lines was based on the assessment of cell culture supernatants by the indirect ELISA of cTn-I. Once cell lines had been established, antibodies were analysed for antigen specificity by ELISA and immunoblotting, which showed the specificity of the 1D12 and 5F4 McAbs for cTn-I from bovine, ovine, rabbit and human cardiac tissue. Both of these $\mathrm{McAb}$ belong to the $\mathrm{IgG}_{1}$ class, an isotype which is preferred for in vivo imaging.

\section{REFERENCES}

Bodor, G., Porter, S., Landenson, J.H. (1990). Human cardiac troponin-I measurement in suspected MI with a double monoclonal antibody sandwich ELISA. Clin. Chem., 36, 1103.

Brekke, C.J., Greaser, M.L. (1976). Separation and characterisation of the troponin components from bovine cardiac muscle. J. Biol. Chem., 251, 866-71.

Cummins, B., Cummins, P. (1987). Cardiac specific troponin-I release in experimental canine myocardial infarction: Development of a sensitive ELISA. J. Mol. Cell. Cardiol., 19, 999-1010.

Cummins, B., Auckland, M.L., Cummins, P. (1987). Cardiac specific troponin-I radioimmunoassay in diagnosis of acute myocardial infarction. Am. Heart J., 113, 1333-44.

Cummins, B., Russell, G., Chandler, S.T., Pears, D.J., Cummins, P. (1990). Uptake of the radioiodinated cardiac specific Tn-I antibodies in myocardial infarction. Cardiovas. Res., 24, $317-27$.

Doran, G.R. and Fleck, A. (1990). Limitations of serum CK-assay in the diagnosis of acute myocardial infarction. Lancet, 336, 697.

Haider, Kh.H. and Stimson, W.H. (1993). Cardiac troponin-I: a biochemical marker for cardiac cell necrosis. Disease Markers., 11, 205-15.

Hunkler, N.M., Kullman, J., Murphy, A.M. (1991). Troponin-I isoform expression in human heart. Circ. Res., 69,1409-1414.

Islam, M.S. and Stimson, W.H. (1987). Production of monoclonal antibodies to Shigella. Lett. Appd. Microbiol., 4, 85-91.

Jin, J-P., Malik, M.L., Lin, J.J-C. (1990). Monoclonal antibodies against cardiac myosin heavy 
chains. Hybridoma, 9, 597-608.

Katagiri, T., Kobayashi, Y., Sasai, Y., Toba, K., Niitani, H. (1981). Alterations in cardiac troponin subunits in myocardial infarction. Jap. Heart J., 22, 653-64.

Katus, H.A., Remppis, A., Looser, S., Hallermeier, K., Scheffold, T., Kubler, W. (1989). Enzyme linked immunosorbent assay of cardiac troponin- $\mathrm{T}$ for the detection of acute myocardial infarction in patients. J. Mol. Cell. Cardiol., 21, 1349-53.

Katus, H.A., Looser, S., Hallermayer, K., Remppis, A., Scheffold, T., Borgya, A., Essig, U., Geub, U. (1992). Development and in vitro characterisation of a new immunoassay of cardiac troponin-T. Clin. Chem., 38, 386-93.

Khaw, B.A., Beller, G.A., Haber, E., Smith, T.W. (1976). Localisation of cardiac specific antibody in myocardial infarction. J. Clin. Invest., 58, 439-46.

Khaw, B.A., Mattis, J.A., Mellincoff, G., Strauss, H.W., Gold, H.K., Haber, E. (1984). Monoclonal antibody to cardiac myosin: Imaging of experimental myocardial infarction. Hybridoma, 3, 11-23.

Kohler, G. and Milstein, C. (1975). Derivation of specific antibody producing tissue culture and tumour lines by cell fusion. Eur. J. Immunol., 6, 511-19.

Lammeli, U.K. (1970). Cleavage of structural proteins during the assembly of the head of bacteriophage T4. Nature, 227, 680-88.

Landenson, J.H., Porter, S., Landt, Y., Bodor, G. (1990). Development and characterisation of monoclonal antibodies specific to troponin-I. Clin. Chem., 36, 1019.

Larue, C., Defacque-Lacquement, H., Calzolari, C., Nguyen, D.L., Pau, B. (1992). New monoclonal antibodies as probes for human cardiac Tn-I: epitopic analysis with synthetic peptides. Mol. Immunol., 29, 271-78.

Larue, C., Calzolari, C., Bertinchant, J-P., Leclerq, F., Grolleau, R., Pau, B. (1993). Cardiac specific immunoenzymometric assay of troponin-I in the early phase of acute myocardial infarction. Clin. Chem., 39, 972-79.

Leger, J.O.C., Bouvagnet, P., Pau, B., Roncucci, R., Leger, J.J. (1985). Levels of ventricular myosin fragments in human sera after myocardial infarction, determined with monoclonal antibodies to myosin heavy chains. Eur. J. Clin. Invest., 15, 422-29.

Mark, D. and Zimmer, A. Fiske-Subarow method: microphosphorous detection. In: Atlas of Clinical Laboratory Procedures, Clin. Chem., Vol. I, 139-42, Mcgraw Hill, New York, 1967.

Morrissey, J.H. (1981). Silver stain for proteins in polyacrylamide gels. A modified procedure with enhanced uniform sensitivity. Anal. Biochem., 117, 307-10.

Nakane, P.K. and Kawaoi, A. (1974) Peroxidase labelled antibody: a new method of conjugation. J. Histochem. Cytochem., 22, 1084-91.

Potter, J.D. and Johnson, J.D. Troponin. In: Cheung, W. (Ed), Calcium and Cell Function. New York, Academic Press, 1982, Vol. II, pp. 145-173.

Prager, N.A., Suzuki, T., Jaffe, A.S., Sobel, B.E., Abendschein, D.R. (1992). Nature and timecourse of generation of isoforms of CK-MB fractions, in vivo. J. Am. Coll. Cardiol., 20, 414 19.

Serrano, S., Chueca, P., Carasco, E., Olaz, F., Zabalegui, A. (1990). Predictive value of myoglobin in early diagnosis of acute myocardial infarction. Ann. Emerg. Med., 19, 953.

Swynghedauw, B. (1986). Developmental and functional adaptation of contractile proteins in cardiac and skeletal muscles. Physiol. Review., 66, 710-71.

Syska, H., Perry, S.V., Trayer, I.P. (1974). A new method of preparation of troponin-I (Inhibitory protein) using affinity chromatography. Evidence for three different forms of $\mathrm{Tn}$-I in striated muscle. FEBS Letters, 40, 253-57.

Towbin, H., Staehelin T., Gordon, J. (1979). Electrophoretic transfer of proteins from polyacrylamide gels to nitrocellulose sheets: Procedure and applications. Proc. Natl. Acad. Sci., 76, 43554.

Tsukui, R. and Ebashi, S. (1973). Cardiac troponin. J. Biochem., 73, 1119-21.

Vaananen, H.K., Syrjala, H., Rahkila, P., Vuori, J., Melamies, L.M., Myllyla, V., Takala, T.E.S. 
(1990). Serum carbonic anhydrase-III and myoglobin concentrations in acute myocardial infarction. Clin. Chem., 36, 635-38.

Verstraete, M. (1992). Advances in thrombolytic therapy. Cardiaovascular Drugs and Therapy, 6, 111-24.

Willerson, J.T. (1989). Clinical diagnosis of acute myocardial infarction. Hospital Practice, 24, $65-77$. 


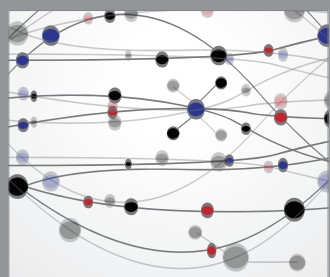

The Scientific World Journal
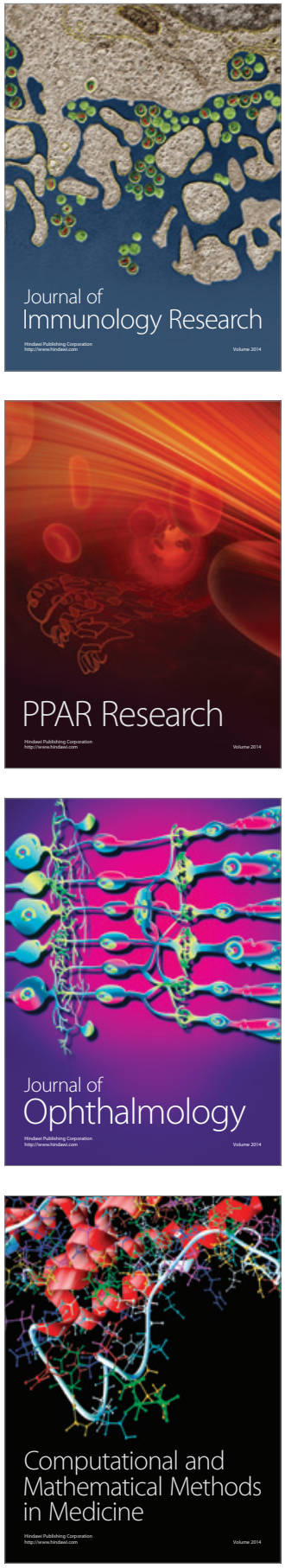

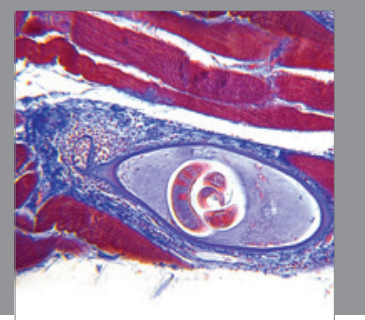

Gastroenterology

Research and Practice
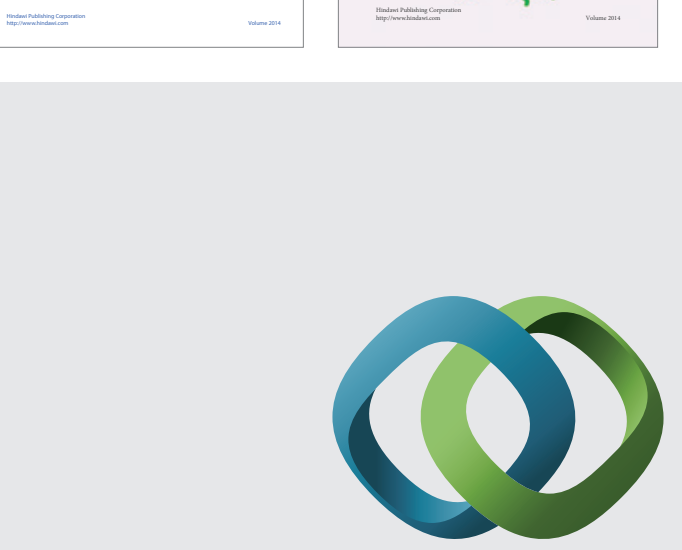

\section{Hindawi}

Submit your manuscripts at

http://www.hindawi.com
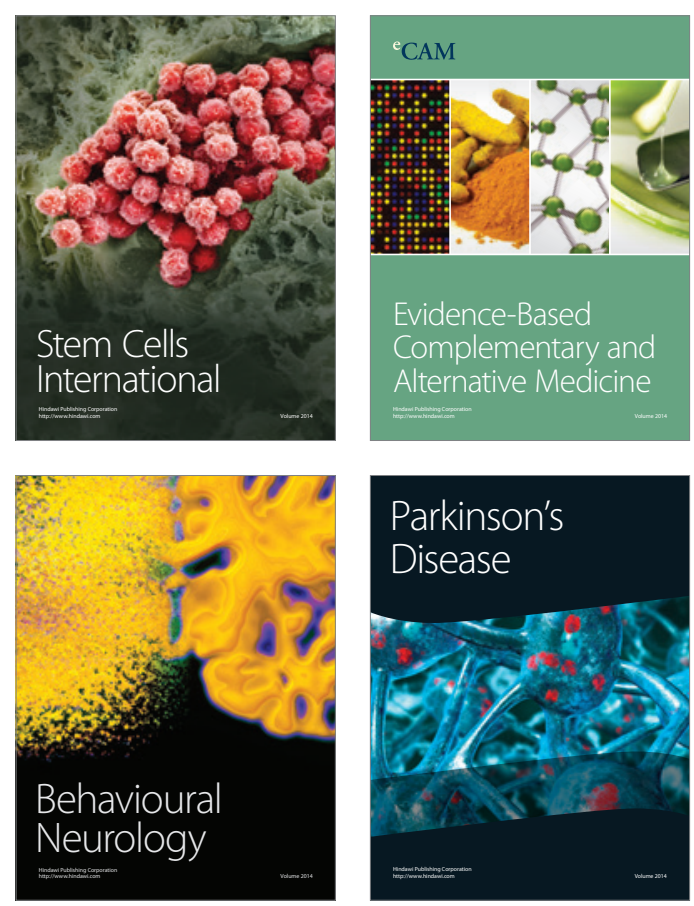

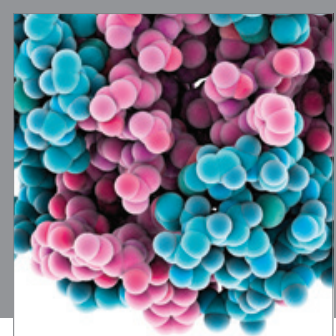

Journal of
Diabetes Research

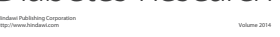

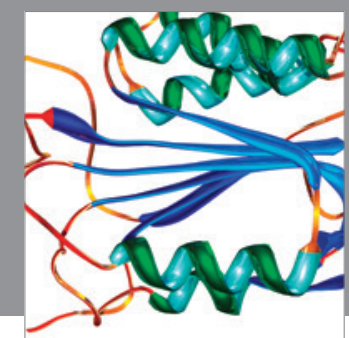

Disease Markers
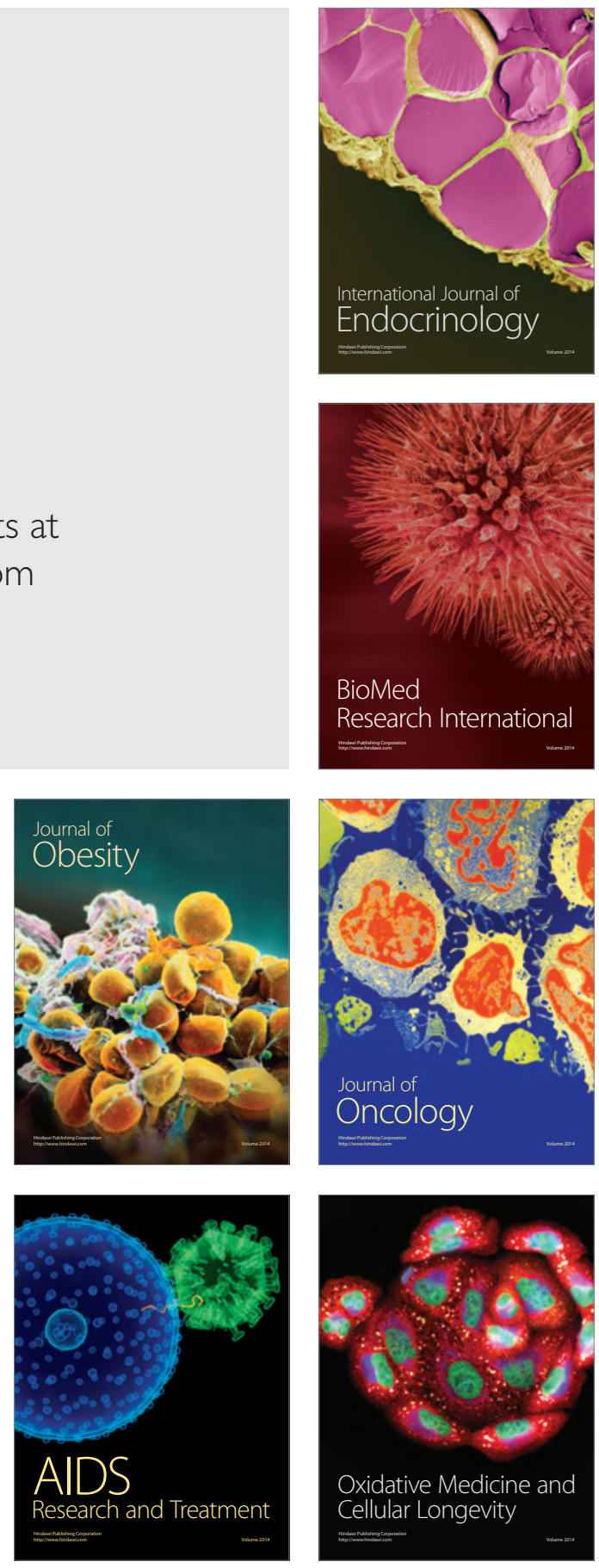